\title{
Research Paper \\ Effectiveness of Compassion-Focused Therapy on Self-Esteem and Resilience in Children and Adolescents with Divorced Parents
}

Zhara Mazaheri ${ }^{1}$, Leila Saadat Mirsifi Fard ${ }^{* 2}$, Vahideh Mohamad Ali Vatankhah ${ }^{3}$, Seyed Ali Darbani ${ }^{4}$

1. M.A. in Career Psychology, Faculty of Educational Sciences and Psychology, University of Isfahan, Iran

2. Ph.D. Student in Counseling, Arak Branch, Islamic Azad University, Arak, Iran

3. M.A. in General Psychology, Roudehen Branch, Islamic Azad University, Roudehen, Iran

4. Ph.D. in Family Counseling, Science and research Branch, Islamic Azad University, Tehran, Iran

Citation: Mazaheri Z, Mirsifi Fard LS, Mohamad Ali Vatankhah V, Darbani SA. Effectiveness of compassion-focused therapy on self-esteem and resilience in children and adolescents with divorced parents. Quarterly Journal of Child Mental Health. 2020; 7(2): $280-293$.

\section{http://dx.doi.org/10.29252/jemh.7.2.24}

\section{A R T I C L E I N F O}

\section{Keywords:}

Compassion-focused, resilience, self-esteem, divorce

Received: 15 Aug 2018 Accepted: 31 Dec 2018 Available: 21 Sep 2020

\section{A B S T R A C T}

Background and Purpose: Parental divorce represents one of the most stressful events for children and adolescents and it has short-term and long-term economic, social, affective and emotional effects on them. This study aimed to investigate the effectiveness of compassion-focused therapy on fostering the self-esteem and resilience in children and adolescents with divorced parents.

Method: This research was a quasi-experimental study with pretest-posttest control group and twomonth follow-up design. The study population included twenty three 10-13-year-old male children and adolescents with divorced parents in Karaj in 2017. After screening with Self-Esteem Scale (Pepper, 1999) and Conner-Davidson Resilience Scale (2003), 20 of these students were selected by convenience sampling and then randomly assigned to either the experimental or control group. The experimental group received eight 90-min weekly sessions of compassion-focused therapy (Gilbert, 2009), while the control group underwent no intervention. Data were analyzed by repeated measure ANOVA.

Results: Findings showed significant difference between the experimental and the control group in terms of self-esteem $(\mathrm{F}=5.67, \mathrm{p}<0.02)$ and resilience $(\mathrm{F}=12.68, \mathrm{p}=0.001)$ at the pretest, posttest and two-month follow-up stages.

Conclusion: Whereas self-esteem and resilience have widespread effects on the quality of interpersonal relations, education, and adjustment of children and adolescents with divorced parents, based on the results of this study, it can be concluded that the compassion-focused therapy increases the self-esteem and resilience of these children by modifying and increasing their interpersonal interactions.

\footnotetext{
* Corresponding author: Leila Saadat Mirsifi Fard, Ph.D. Student in Counseling, Arak Branch, Islamic Azad University, Arak, Iran. E-mail addresses: Pajoohesh59@gmail.com
} 


\section{تأثير درمان متمر كز بر شفقت در تقويت حرمت خود و تابآورى كود كان و نوجوانان داراى والدين طلاق كرفته}

\section{زهر ا مظاهرى'، ليلاالسادات ميرصيفى فرد*، وحيده محمدعلى وطن خواهّ، سيد على دربانى}

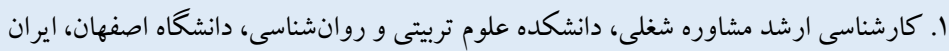

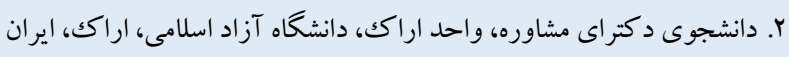

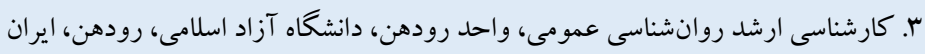

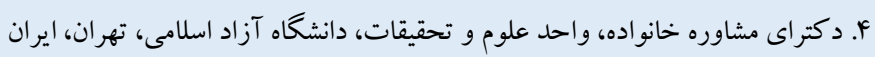

\begin{tabular}{|c|c|}
\hline جكيده & 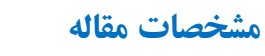 \\
\hline زمينه و هدف: طلاق والدين، يكى از عمده ترين رويدادهاى تنشخر است كه كود كان و نوجوانان با آن مواجه مىشوند و اثرات كو تاهمدت & 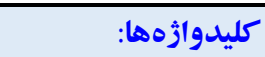 \\
\hline و بلندمدت اقتصادى، اجتماعى، عاطفى، و هيجانى بر كود كان و نوجوانان به جاى مى گذارد. هدف اين يُووهش تعيين اثربخشى درمان & 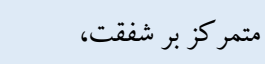 \\
\hline متمر كز بر شفقت در تقويت حرمت خود و تابآورى كود كان و نوجوانان داراى والدين طلاق گرفنه، بود. & حرمت خود، \\
\hline 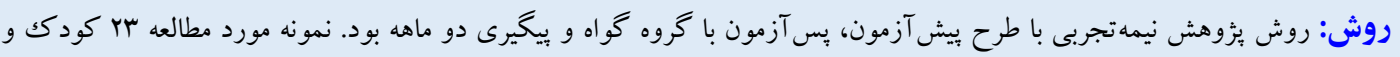 & 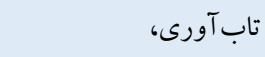 \\
\hline 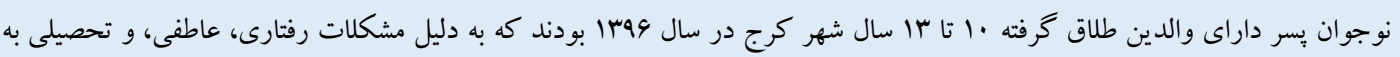 & طلاق \\
\hline مركز مشاوره آموزش و يرورش ناحيه الكرج ارجاع داده شده بودند كه پِس از غربالكرى با يرسشنامه حرمت خود بِب (1999) و تاب آورى & \\
\hline كانر و ديويدسون (r..r) به صورت در دسترس ·r نفر از آنها انتخاب، و به صورت تصادفى در دو گروه آزمايش و گواه جايدهى شدند. & \\
\hline 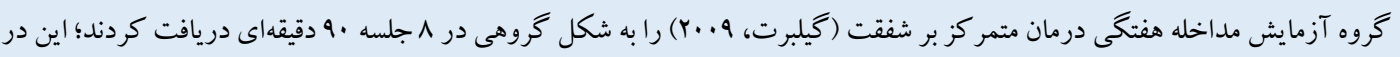 & \\
\hline حالى بود كه گروه گُواه، هيج مداخلهاى را دريافت نكردند. دادهها با استفاده از آزمون تحليل واريانس اندازه گيرى مكرر تحليل شد. & \\
\hline 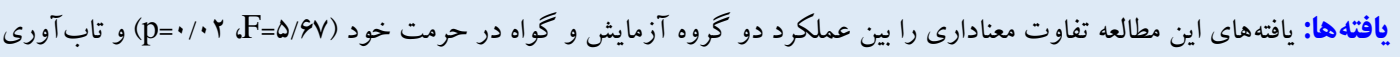 & \\
\hline 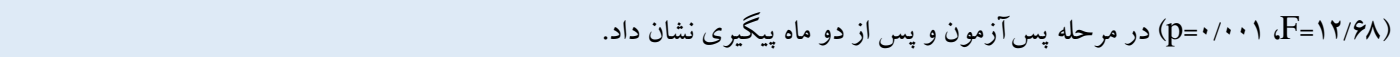 & \\
\hline نتيجه كيرى: با توجه به اينكه ميزان حرمت خود و تاب آورى به شكل گتسردهاى بر كيفيت روابط ميانفردى، تحصيلات، و سازشيافتىى & 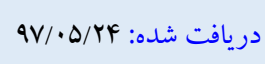 \\
\hline كود كان و نوجوانان داراى والدين طلاق كرفته اثر كذار است، بنابراين مىتوان نتيجه گيرى كرد كه مداخله درمان متمركز بر شفقت با اصلاح & 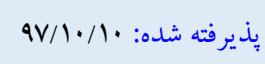 \\
\hline و افزايش تعامل هاى بين فردى، باعث افزايش حرمت خود و تاب آورى كود كان و نوجو انان مىشود. & منتشر شده: آ آ99/99 \\
\hline
\end{tabular}

* نويسنده مسئول: ليلاالسادات ميرصيفى فرد، دانشجوى دكتراى مشاوره، واحد اراك،، دانشكاه آزاد اسلامى، اراكى، ايران.

Pajoohesh59@gmail.com : رايانامه

تلفن: 
(9)؛ بنابر اين مؤلفه اصلى حرمت خود، ارزيابى خودهاست كه از روند

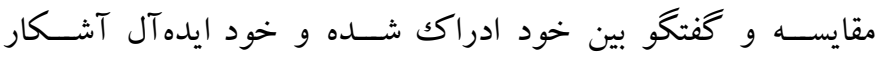
مىشـود(V). حرمت خود يكى از اسـاسىترين عوامل در تحول مطلوب

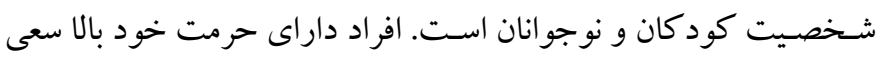
مى كنند خود را با تغييرات محيط وفق دهند، تمايل به بذيرش و اصسلاح اشتباه خود دارند و نوعدوستى و علاقه به همكارى در آنها ديده مى بـودي؛ در حالى كه افراد داراى حرمت خود پيايين از احساس كهترى؟، احساس

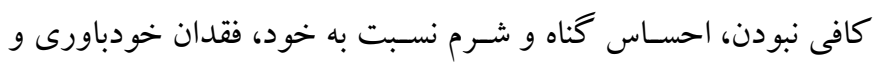
خوديذيرى، بى اعتمادى به خويشتن، و دوست نداشتن خود رنج مىبرند.

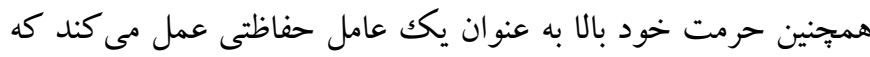

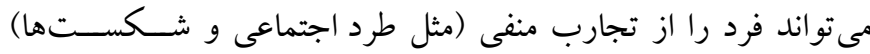

محافظت كند (ه).

علاوه بر آن، در مباحث مربوط به فرزندان طلاق، مفهوم تاب آورىى

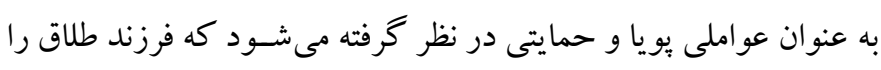

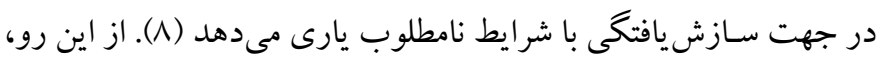

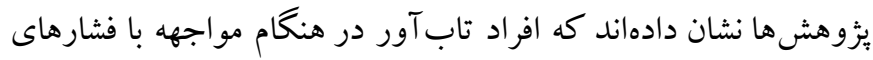

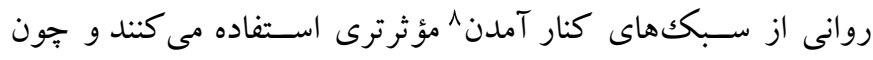

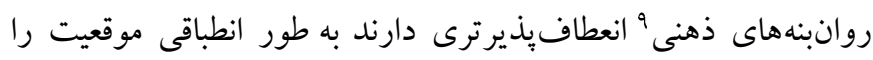

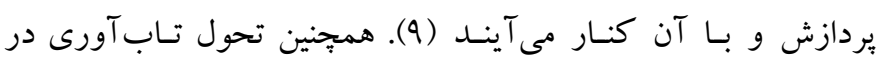

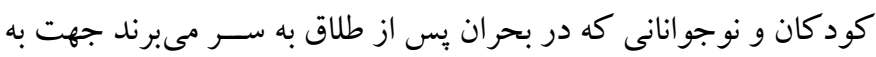

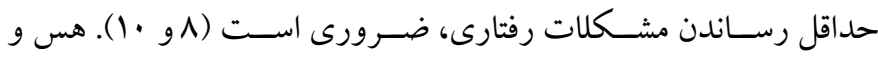

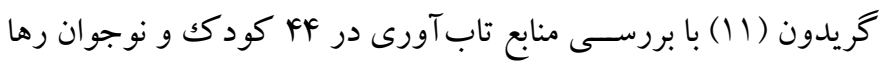

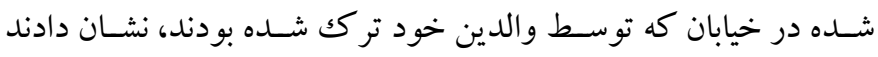

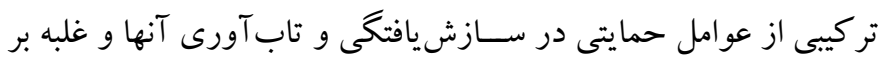

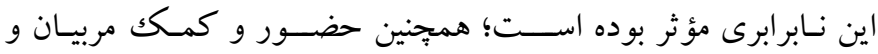
درمانكران و نيز داشتن دوستان هم سنى كه فرد بتواند با او تبادل اطلاعات

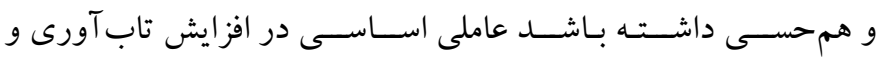

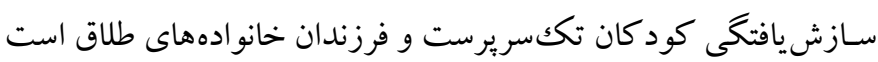
(•). افزون بر آن، هر ساله تعداد زيادى از كودكان و نوجوانان انحلال

6. Inferiority feeling

7. Resiliency

8. Coping styles

9. Mental schemas
مقلهم

طلـاق' بـهـ عنوان يكى از تنش آورترين عوامـل مى توانــ ســاخـتهاى

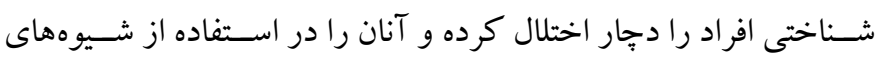

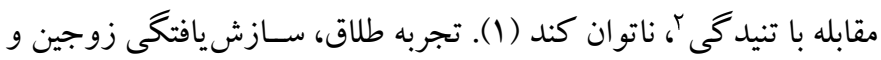

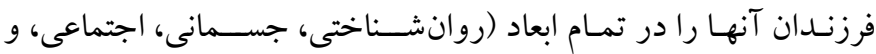

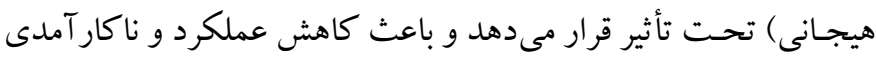

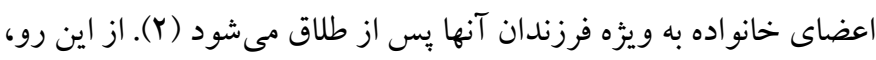

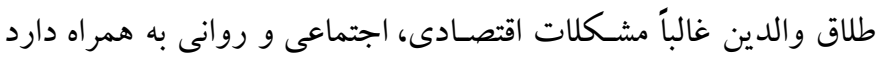
و جنين تغييراتى باعث مى شـود فرزندان آنها احسـاس عصبانيت، خشم،

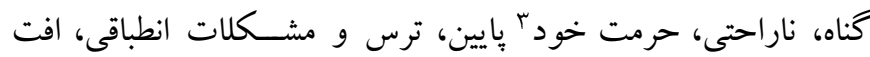

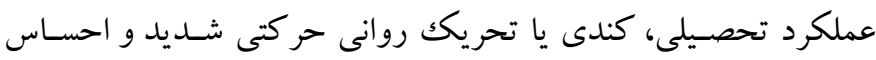

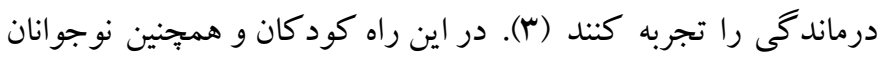

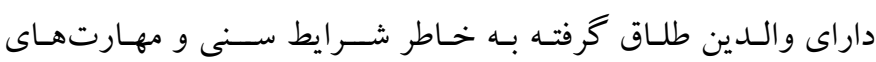

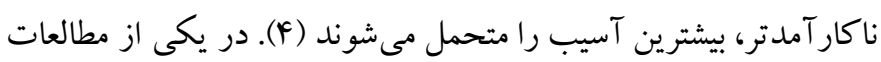

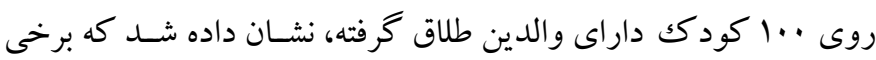
از ييامدهاى نامطلوب طلاق بر كود كان از منظر خود آنان عبارتاند ازئ

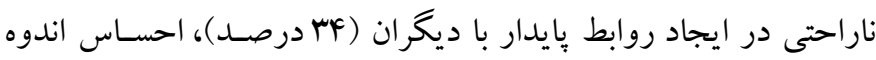

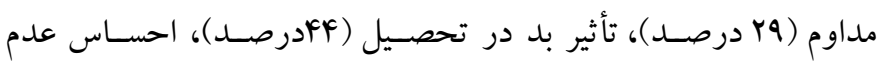

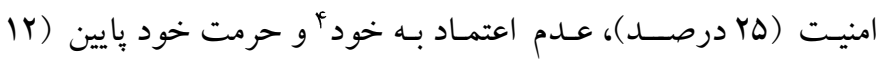
درصسـد)، كـاهش تعداد اقوام و آدمهاى مهم (F) (أدرصــد)، علائم

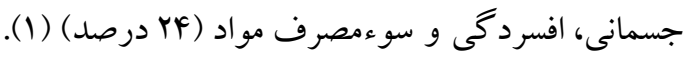
يكى از عوامل روانشـناختى مؤثر بر سـازش يافتكى با طلاق والدين،

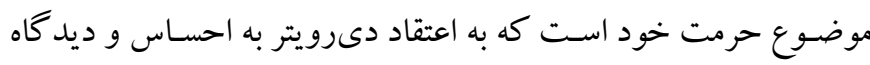

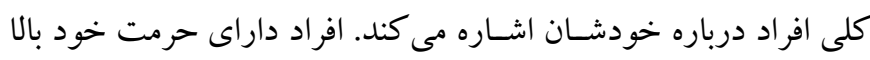
مسئوليت رفتار و انتخابهاى خود را مى يذيرند، داراى احسـاسـات و

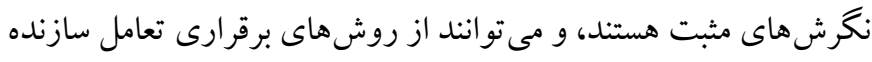

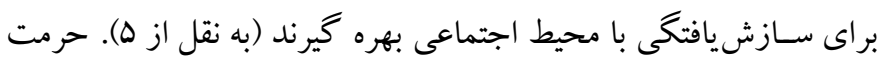

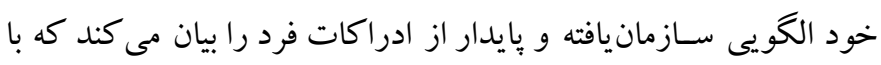
تجربه فرد و تفسير ديخران از آن تجربه شكل گرفته و متحول مى بـود

1. Divorce

2. Stress

3. Self-esteem

4. Self confidence

5. Self-assessment 
بر پايه مراقبه مبتنى بر شـفقت اسـت و درمان مبتنى بر شـفقت با هدف كمـك به افراد براى يادگيرى مهارت هاى كليدى مورد نياز به منظور

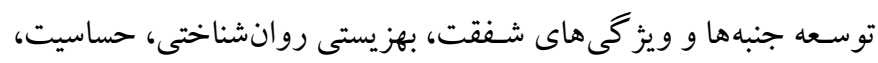

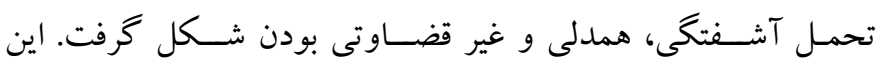

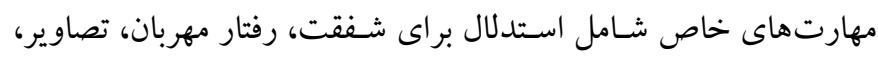
ظاهر، و احسـاسـات مشـفقانه اسـت (19). در اين مورد، برخى مطالعات

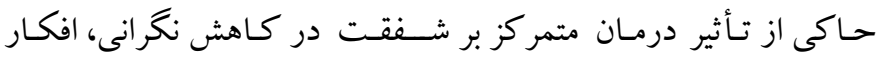

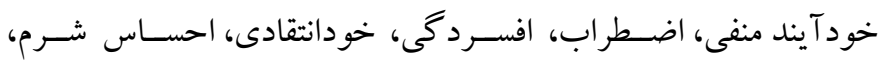

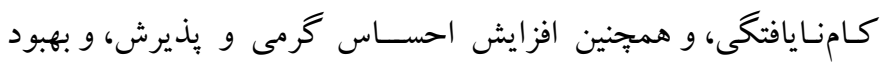
حرمت خود بودند (ها). علاوه بر اين، درمان متمركز بر شفقت از طريق برئ

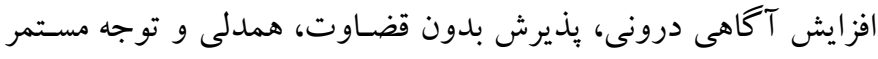

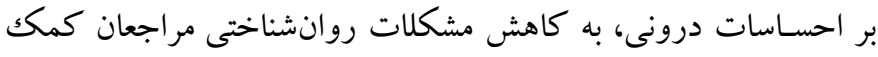

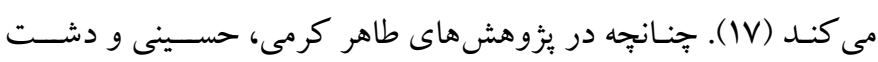

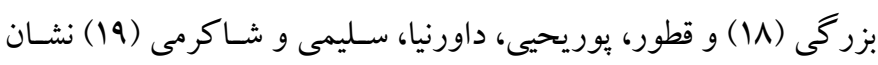
داده شــــ كه درمان متمركز بر شــفقت مى تواند تاب آورى راد در افراد

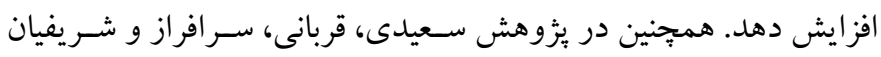

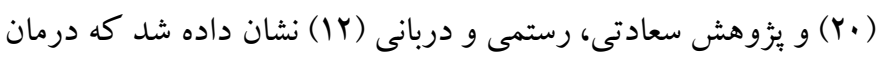
متمر كز بر شفقت، بر حرمت خود و سازش يافتكى نيز مؤثر است. تروميتر

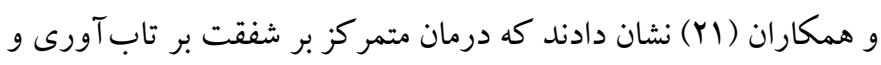

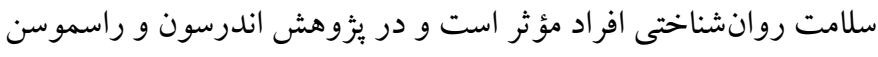

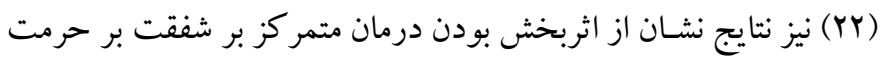
خود و خودينداشت كود كان و نوجوانان دارد.

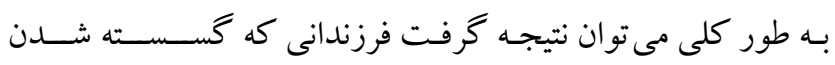

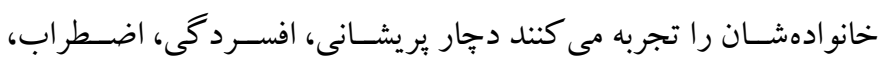

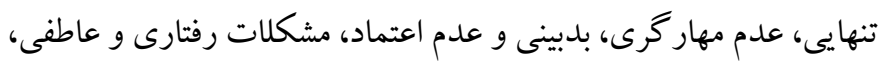

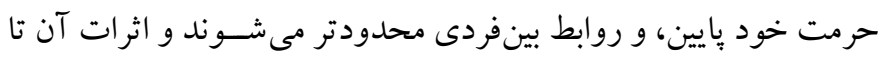

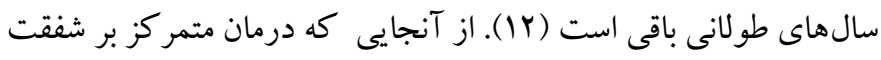

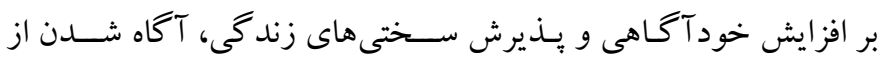

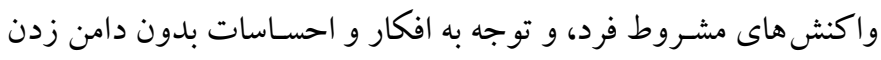

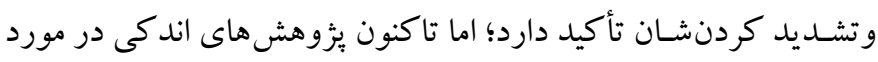

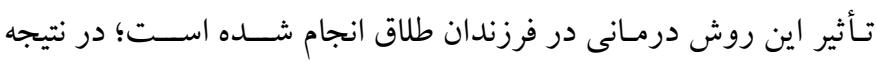

ازدواج والدين خود را تجربه مى كنند و بايد مجموعه تغييرات زندگى

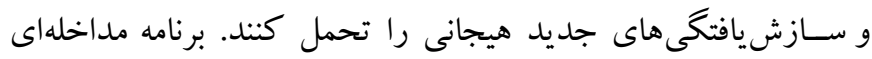

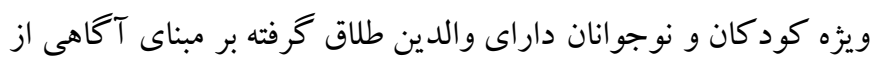

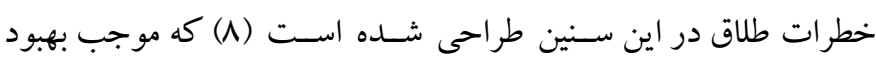
يميامدهاى فرزندان طلاق مىشـود. همجنين براى تغيير و كاهش بيامدهاى

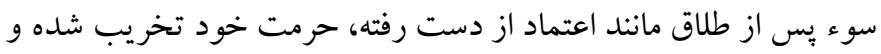

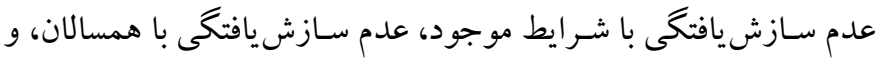

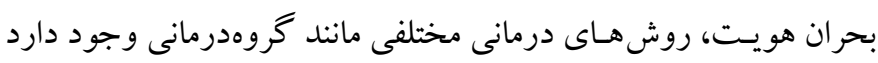

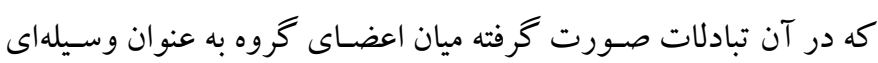
مؤثر در ايجاد اين تغيير و تحول و حمايت، در نظر كرفته مى نــود (Y) (I).

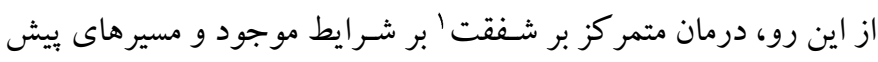
رو به سـمت بذيرش و تحول شخصى در بحر انهاى ناشى از طلاق بسيار

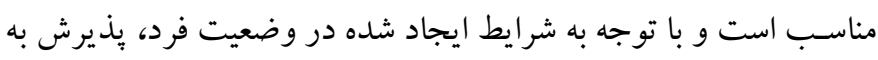

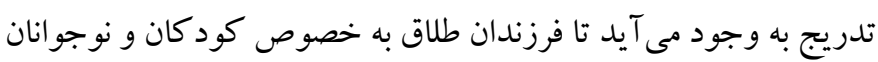

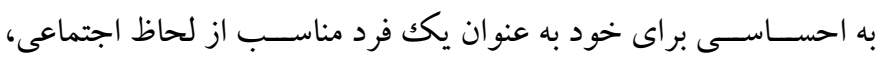

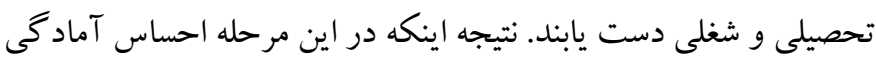

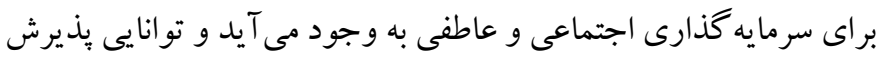

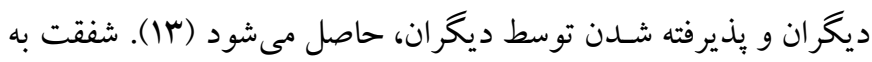

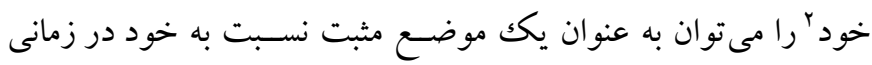

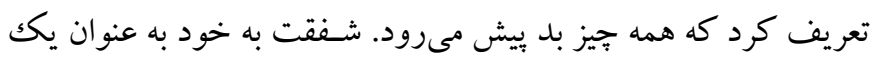

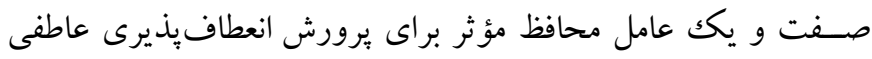

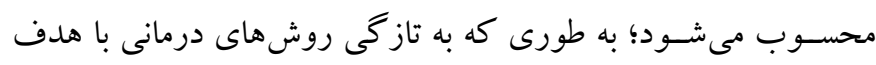
بهبود شفقت به خود، كسترش يافتند (If). اصسول پايه در درمان مبتنى بر شـفت به اين موضسوع اشاره مى كند

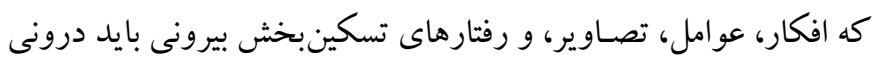

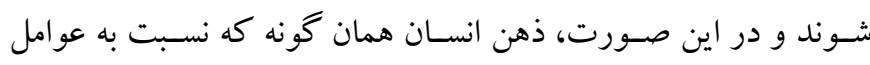

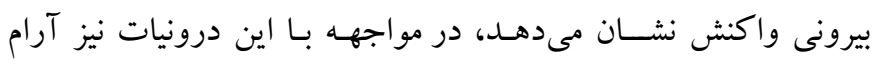

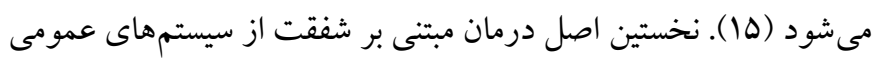
تنظيم احسـاسـات شـامل سـيستم تهلديد و حفاظت از خود، سـيستم هيجانات، و سيستم حمايت اجتماعى برخاسته است و هدف از اين نوع درمان، ايجاد تعادل بين اين سـه سيستم است. هسته اصلى شفقت درمانى 
انحراف معيـار /9/· بود. بيشـترين فراوانى در گروه آزمـايش و گواه

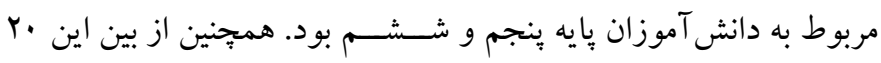

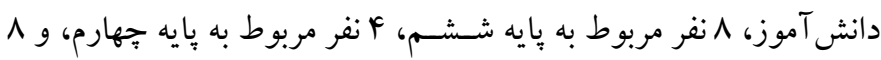
نفر نيز مربوط بـه بايه بنجم بودند. همجنين از نظر وضـعيت اقتصسادى،

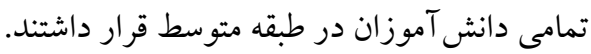

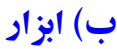

1. بِرسـشـنامه حرمت خود ': اين مقياس توسـط بِّ در سـال 1919 به منظور بررسى ميزان حرمت خود كود كان و نوجوانان طراحى شـد. اين

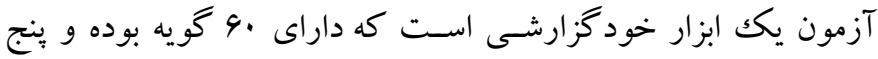

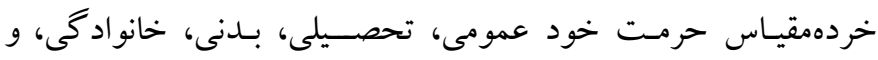

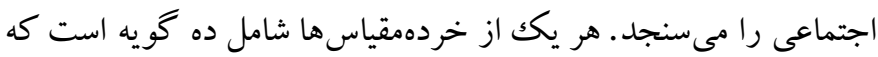
بر اسـاس طيف ليكرت سـه درجهاى (تقريباً هميشه = r تا تقريباً هيج

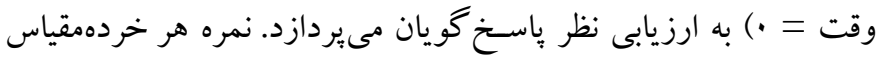

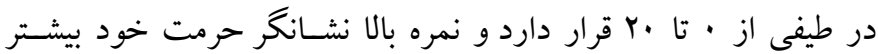
آزمودنى در خردهمقياسهاى مورد نظر اسـت (به نقل از سب). نمره بالا در كل خردهمقياسها نيز حرمت خود بيشتر آزمودنى را نشان مى مدهدهد.

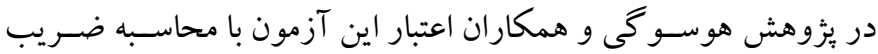

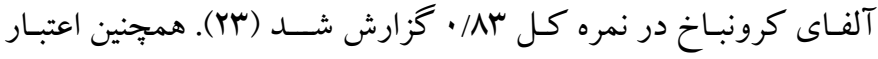

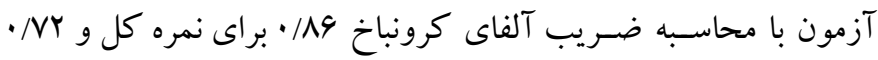

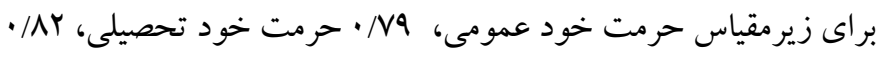

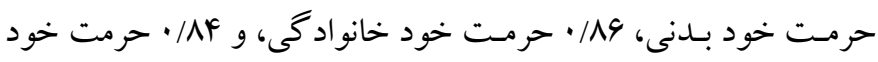

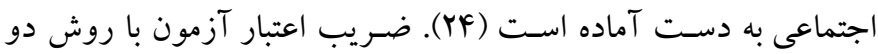

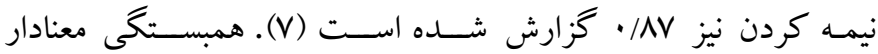

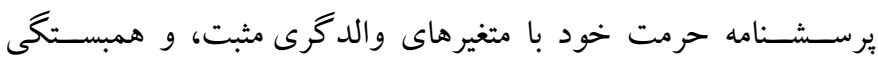

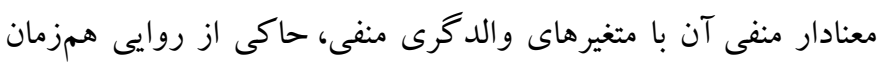

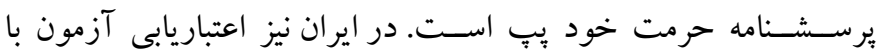
استفاده از از دو روش همسانى درونى و تحليل عاملى انجام شده است

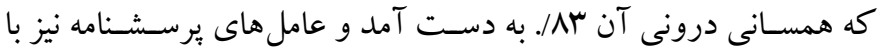
روش تحليل عاملى مورد تأييد قرار گرفته است (V).

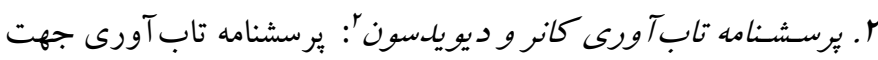

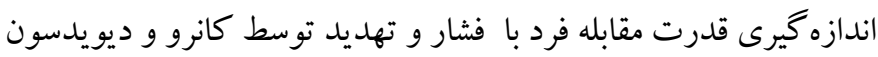

بررسـى تأثير اين روش درمانى در كودكان و نوجو انان با والدين طلاق كرفته، ضرورت دارد. بدين ترتيب هدف اين بثزوهش بررسى تأثير درمان

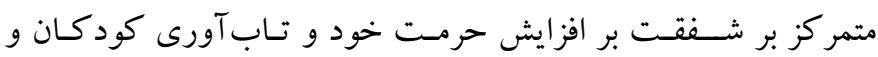
نوجوانان داراى والدين طلاق گرفته است.

روش الف) طرح بزوهش و شـر كت كنند كان: يُزوهش حاضر نيمه تجربى با

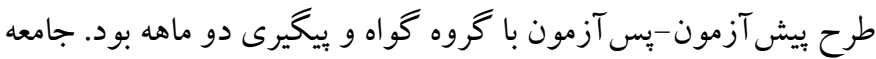
آمارى اين يُوهش شــامل كود كان و نوجوانان يسـر ( •ا تا سا ســال)

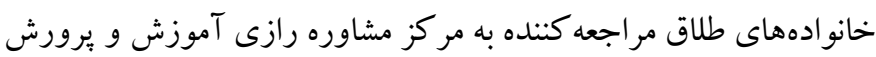

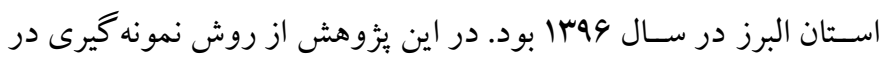
دسترس استفاده شده است؛ به اين صورت كه در ابتدا پس از اخذ مجوز

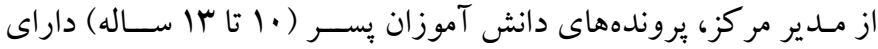

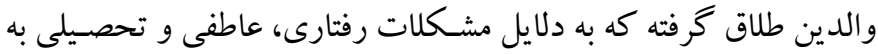
مر كز مشاوره ناحيه يكك كرج ارجاع داده شده بودند، بررسى شد. بـ بـ از

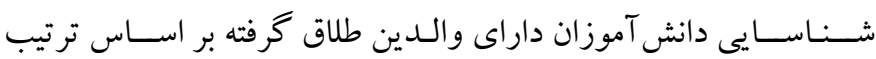

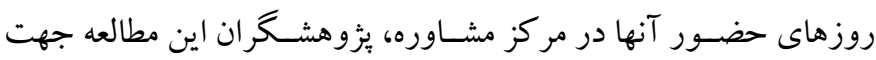
اجرا و غربالخرى در مركز مشاوره حضور يافتند و به اجر ای برسشنامههاى

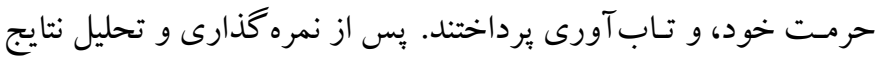

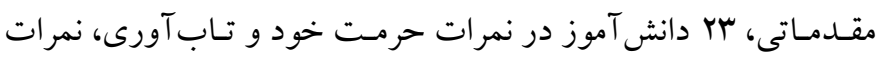

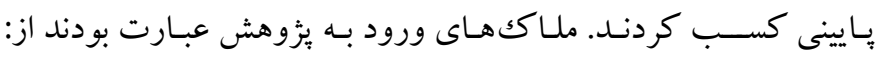

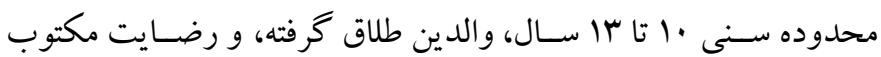

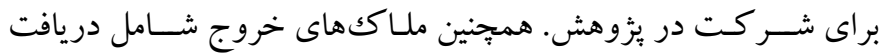

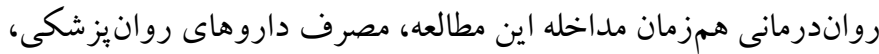

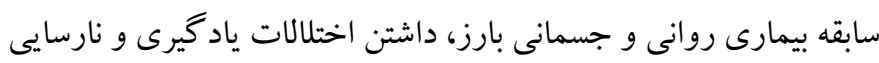

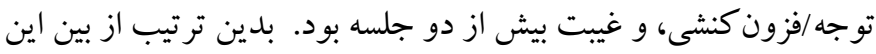

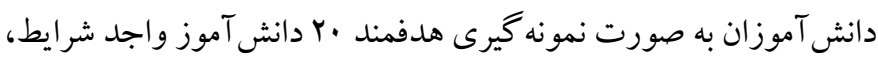

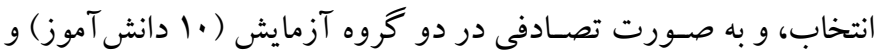

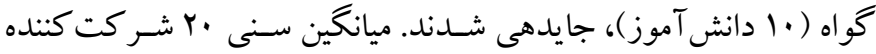

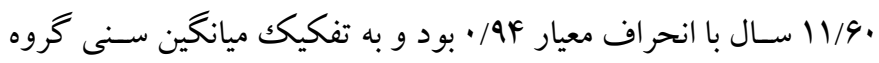

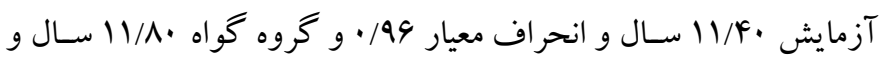


ج) برنامه مداخله: برنامه مداخلهاى به كار گرفته شده در اين مطالعه،

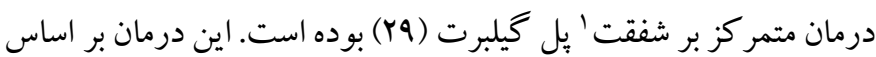
يافته هاى روانشناسى تحولى، علم عصب يايه عاطفى، فلسفه عملى بوديستى، و نظريه تكاملى، شكلى جامع از رفتاردرمانى تجربى را تدوين كرده است كه به نام درمان متمر كز بر شفقت شناخته مىشود. گيلبرت شفقت را به عنوان فرايندى جندوجهى توصيف مى كند كه از ذهنيت مراقبت كننده، تكامل يافته و در مراقبت والدينى و يرورش كودكك يافت مىشود. شفقت داراى تعدادى عناصر هيجانى، شناختى، و انخيزشى نيز هست كه در توانايى ايجاد فرصتهايى براى تحول و تغيير همراه با ملايمت و مراقبت نقش دارند. بدين ترتيب يروتكل جلسات درمان متمر كز بر شفقت بر اساس فعاليتهاى يثزوهشى گيلبرت (ها) و درمان

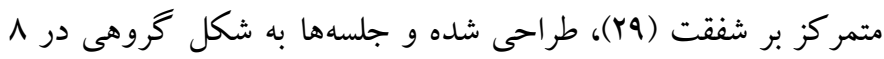
جلسه به مدت •9 دقيقه و در روزهاى يكشنبه و سهشنبه هر هفته در مركز مشاوره رازى ناحيه Y كرج اجرا شد. در جدول ا، خلاصه ساختار كلى درمان متمر كز بر شفقت بر اساس مفاهيم گيلبرت ارائه شده است.
(YD) با مرور منابع يزٔوهشى (1991-19V9) حوزه تابآورى تدوين شده اســت. آنهـا معتقــند كه اين ابزار قادر به تفكيكك افراد تابـآور از غير تاب آور اسـت. يرسـشنامه تابآورى هY گ گيه دارد و در مقياس ليكرت

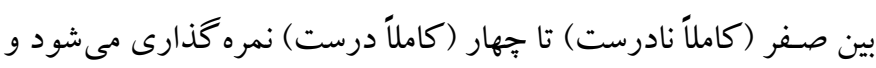
داراى يكك نمره كل اسـت. بيخدلى، نجفى و رسـتمى، همسـانى درونى اين مقياس را بر اســاس آلفاى كرونباخ •9/، • گزارش كردند (Y). كمبل- ســلس و اسـتين، مقياس اوليه تابـآورى را بر روى نمونهاى اها نفرى هنجاريابى و شـاخصهاى روانسـنجى آن را تأييد كردند (YV) (YV) روايى سـازه مقياس جديد تابآورى بر اسـاس تحليل عاملى تأييدى با بار عاملى بين FF تا سه صـدم حاكى از روايى سـازه مطلوب و قابل قبول براى اين مقياس اسـت؛ همجنين اعتبار اين برسـشــامه با اسـتفاده از آزمون ضريب آلفاى كرونباخ مورد آزمون قرار كرفت كه F/A • به دسـت آمد (YN)؛ بنابراين اين ابزار از شــاخصهاى مطلوبى برخوردار اسـت. در يثروهش حاضـر نيز ضـريب آلفاى كرونباخ برابر با 9 به دست آمد.

جدول ا: ساختار كلى درمان متمر كز بر شفقت بر اساس مفاهيم كيلبرت

\begin{tabular}{|c|c|c|c|c|}
\hline رفتار مورد انتظار & 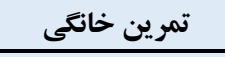 & محتواى جلسات & اهداف & جلسات \\
\hline شناسايى و آكاهى از & 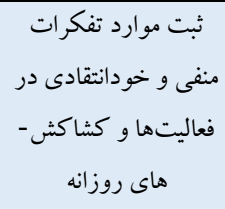 & 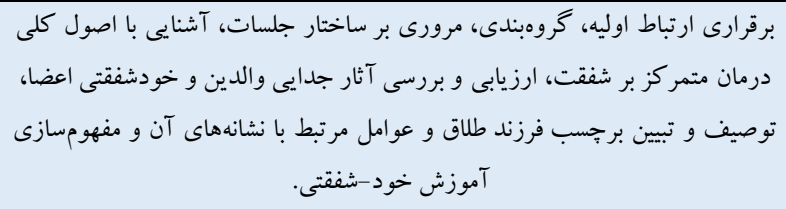 & آشنايى با اصول كلى درمان & 1 \\
\hline مؤلفهايى خودشفقاسى و آكاهى از & خو ثبت مؤلفههاى & 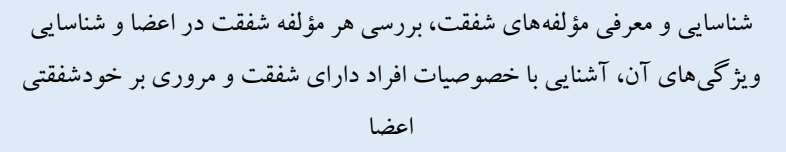 & شناخت مؤلفههاى شفقت خود & r \\
\hline مؤلفهايى خودشفقتى و آكاهى از & 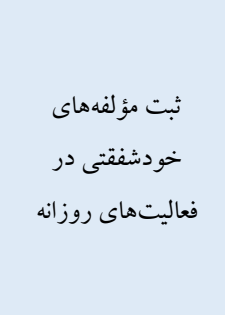 & 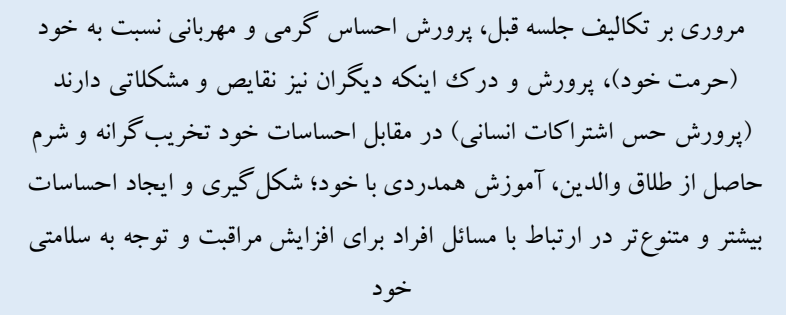 & آموزش و يرورش خودشفقتى اعضا & $r$ \\
\hline يرورش خودشفقتى & ثبت اشتباهات روزانه و & 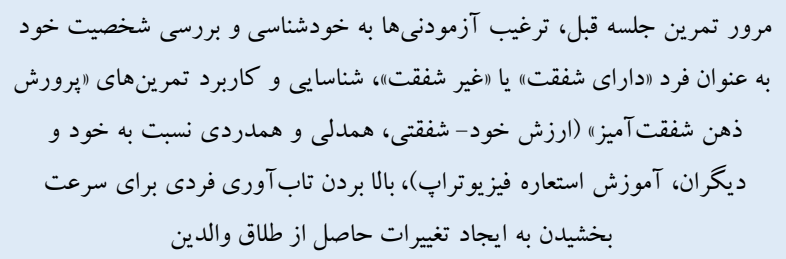 & خو خشناسى و شناسايى عو امل & f \\
\hline
\end{tabular}




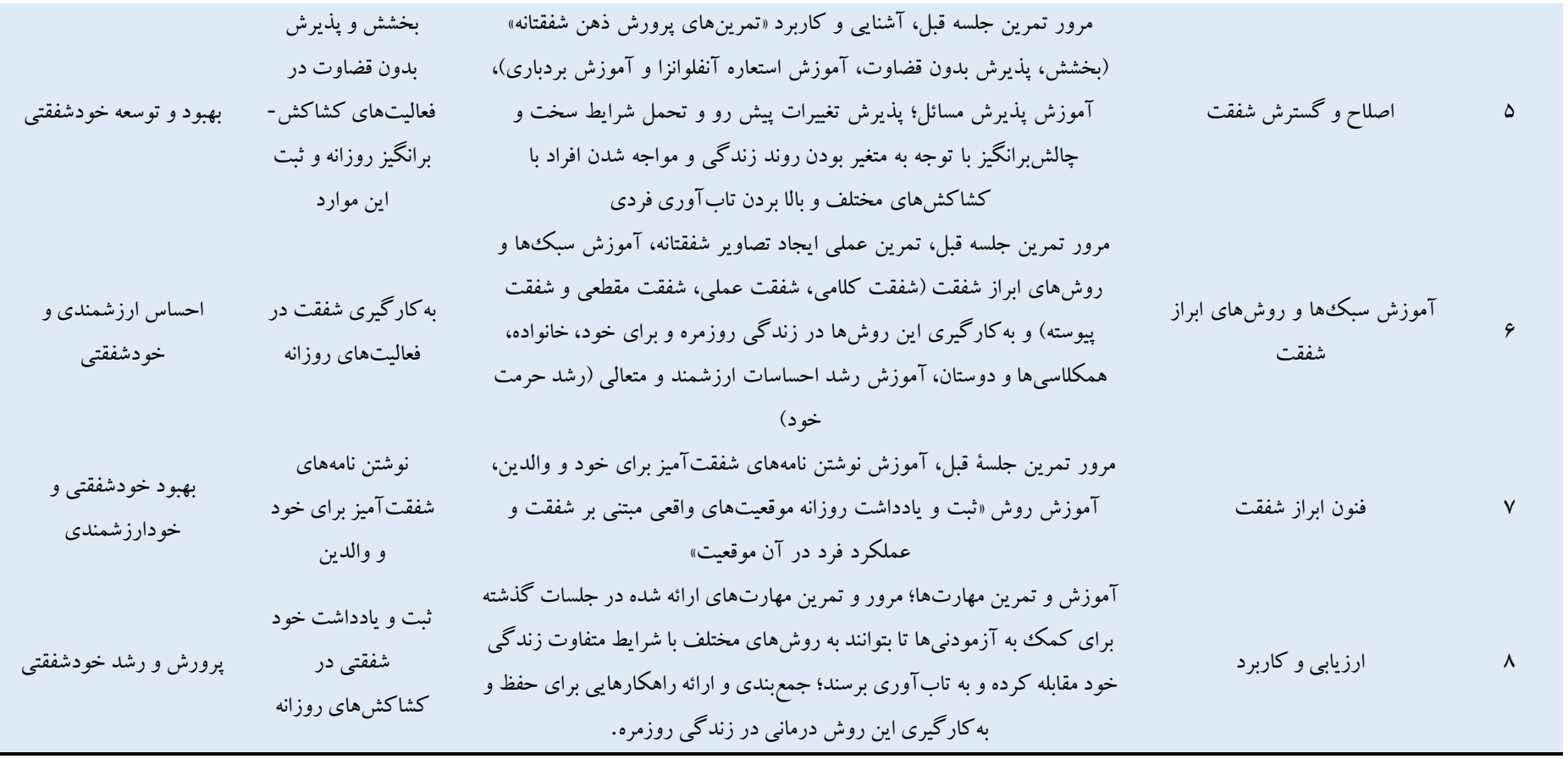

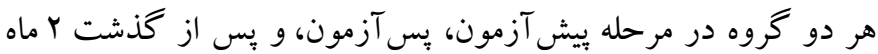
در مرحله يِيخيرى مورد ارزيابى قرار گرفتند در پايان دادههاى به دسـت آمده از طريق تحليل واريانس اندازه گيرى مكرر تحليل شد.

بافتهانها

در جدول Y شـاخص هاى توصسيفى متغيرهاى يثوهش، شـامل ميانخين و

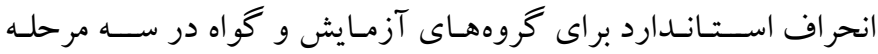

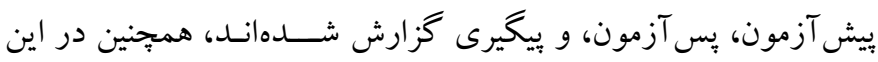
جدول نتايج آزمون كالمو گر اف -اســميرنف براى بررسـى نرمال بودن توزيع دادهها ارائه شدهاند.
د) روش اجر ا: بعد از كسب مجوز و هماهنگیى با مدير مركز مشاوره و توجيسه دانش آموزان مراجعسه كنتـده،افراد نموه انتخـاب و در دو كروه آزمايش و گو اه جايدهى شـدند. گروه آزمايش با رعايت اصول اخلاقى (ماند رازدارى، رضايت كتبى جهت شركت در مطالعه و ... ) و با توجه به محدوديت زمانى، جلسـه هاى مداخله را به شـكل گروهى در ^ جلسه به مدت •9 دقيقه و در روزهاى يكشـنبه و سـهـشـبه هر هفته در مركز مشـاوره رازى ناحيه r كرج توسط نويسنده دوم و جهارم مقاله، دريافت كردنـد. افراد كروه گواه هيج نوع درمـانى را در اين مسدت دريـافـت نكردند، ولى به دلايل مسائل اخلاقى به كروه گو اه تعهد داده شد كه يس از يـايان جلســهها كروه آزمايش، نيز به طور خلاصسه تحت درمان قرار خواهند كرفت (لازم به ذكر اسـت اين آموزش انجام شـده است). سيس

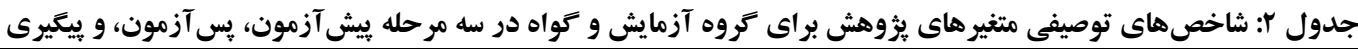

\begin{tabular}{|c|c|c|c|c|c|c|}
\hline سطح معنادارى & آماره k-S Z & انحر اف استاندارد & ميانغين & كروه & مرحله & متغير \\
\hline .190 & $\cdot / N r$ & $1 / \wedge 9$ & $r V / 9$. & آزمايش & \multirow{2}{*}{ ييش آزمون } & \multirow{6}{*}{ رمت خود } \\
\hline$\cdot / 90$ & $\cdot / \Delta$ & I/AV & $r \Lambda / r$. & كواه & & \\
\hline$\cdot / \Delta r$ & $\cdot / A \cdot$ & I/AV & Fr/T. & آزمايش & \multirow{2}{*}{ يس آزمون } & \\
\hline$\cdot / r 1$ & $1 / \cdot 0$ & $Y / M \Lambda$ & rN/VD & كواه & & \\
\hline$\cdot / \mathrm{VA}$ & .190 & $r / r)$ & $F i / v$. & آزمايش & \multirow{2}{*}{ ييخيرى } & \\
\hline$\cdot / \cdot \wedge$ & $I / Y F$ & $1 / V F$ & rN/TG & كواه & & \\
\hline$\cdot / r$. & $\cdot / \Lambda$ & $1 / Y^{4}$ & 1.19 & آزمايش & ييش آزمون & خردهمقياس عمومى \\
\hline
\end{tabular}




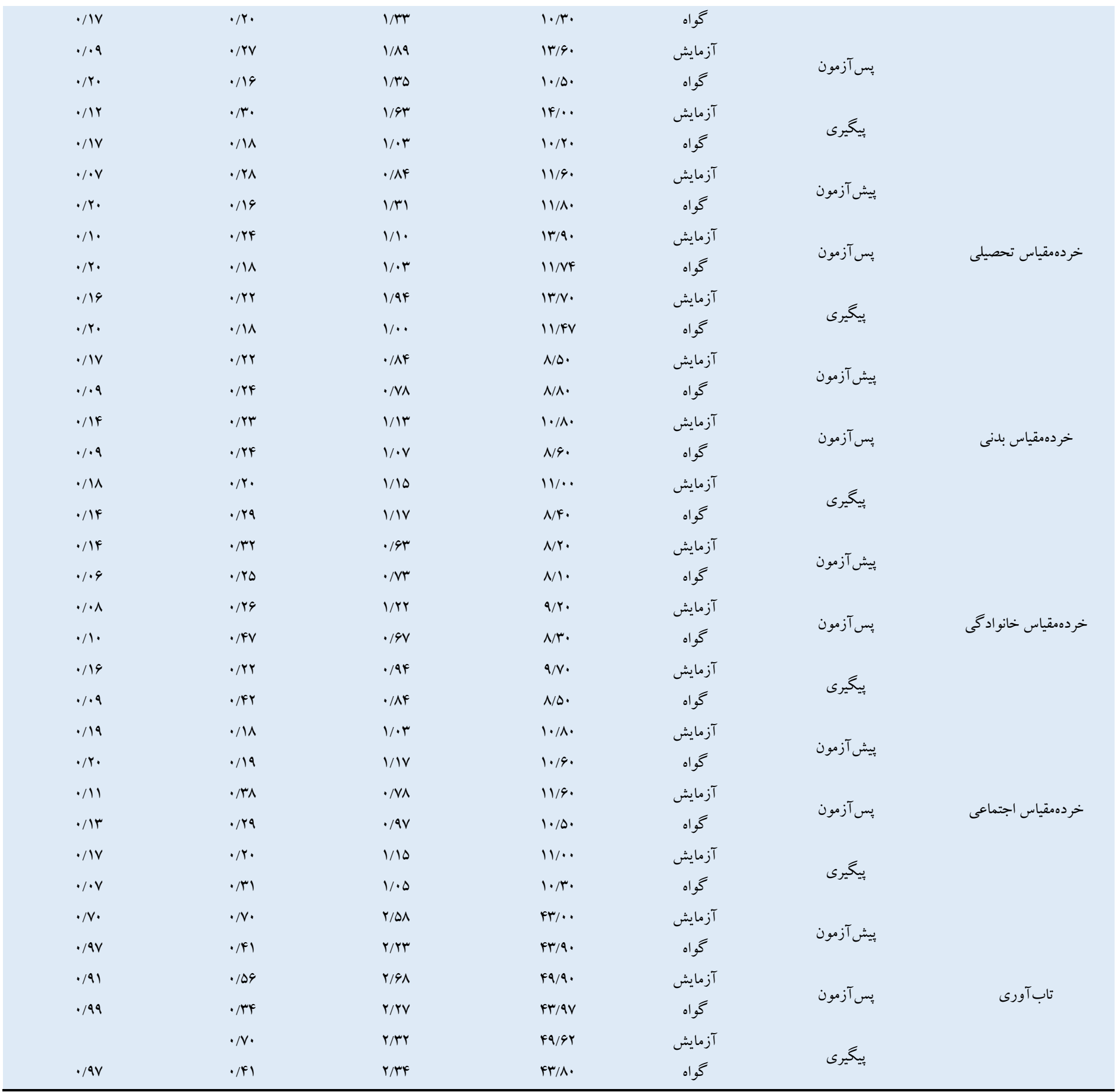

مرحله پِ آزمون تا مرحله بيخيرى نيز كاهش داشـته اسـت؛ اما ميانگين

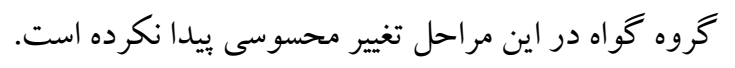

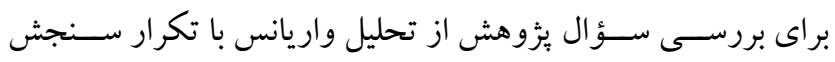

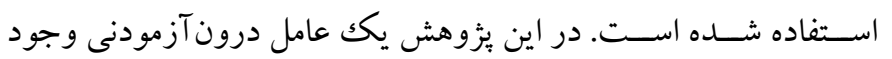
داشـت كه آن عضـويت گروهى بود؛ بنابر اين طرح مورد استـفاده طرح
با توجه به نتايج جدول r، آماره Z آزمون كولمو گراف-اسـميرنف

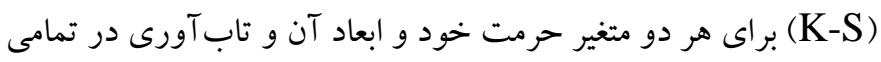

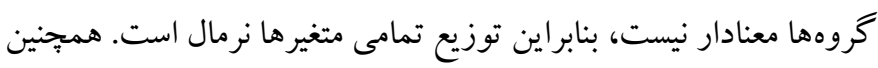
يـافتههـاى جدول فوق نشــان مى دهد كه در متغيرهاى بثزوهش ميانكين

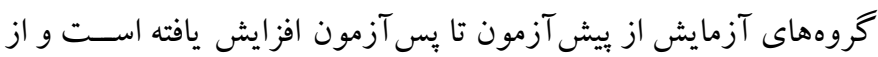


مىشــود. در جـدول ب نتايج آزمون مو جلى جهـت بررسـى كرويـت متغيرهاى يُوهش كز ارش شده است.
درون-بين آزمودنى اسـت. در اين بخش نتايج آزمون تحليل واريانس با

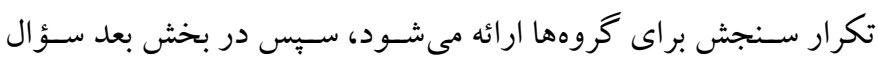

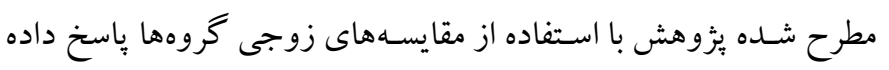

جدول rا: نتايج آزمون موجلى متغيرها

\begin{tabular}{|c|c|c|c|c|c|c|}
\hline إيسيلون هاين-فلت & إيسيلون كرين هاوس-تيسر & سطح معنادارى & درجه آزادى & مجذور خى & موخلى W & متغير \\
\hline .191 & $\cdot / \Delta 9$ & $\cdot / \cdots$ & r & $r F / Q$. & 每 & حرمت خود \\
\hline$\cdot / v$ & $\cdot / 94$ &.$\cdot \cdot 1$ & $r$ & $\mid F / Y F$ & $\cdot / 4 \pi$ & تاب آورى \\
\hline
\end{tabular}

با توجه به جدول "ا، مقدار إيسيلون شاخصهاى گرين هاوس - كيسر

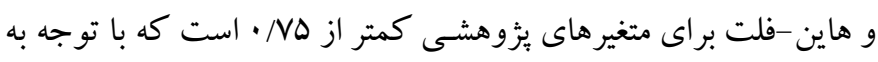

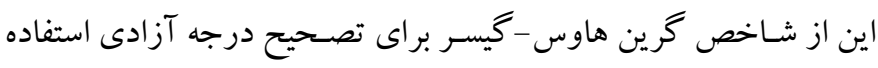

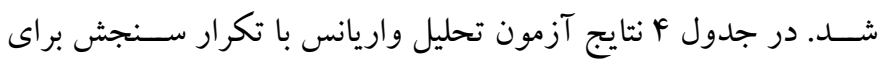

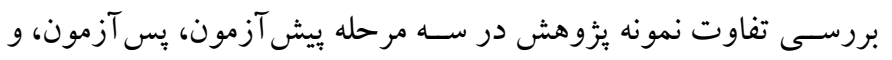

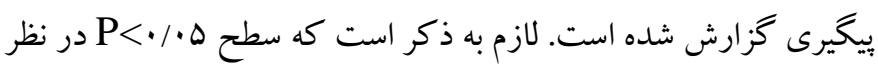

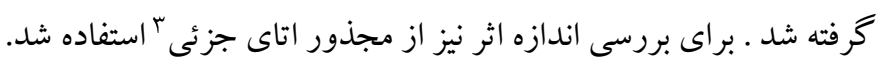

نتـايج جـدول ب نشــان مىدهد كه آماره W مو جلى براى متغيرهاى

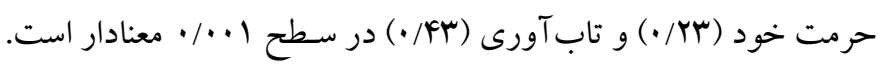
اين يافته نشـان مىدهد كه واريانس تفاوتها در بين سطوح متغير وابسته

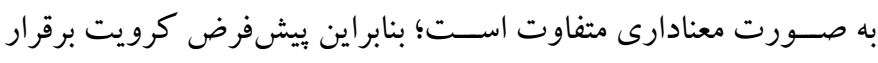

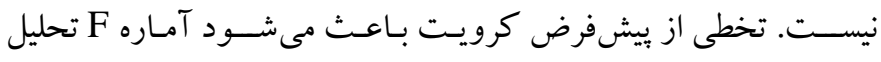

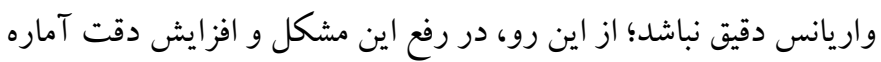

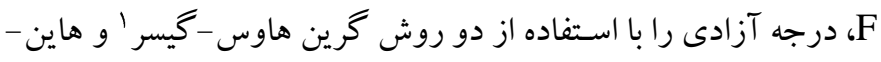
فلت تصحيح شد.

جدول ع: نتايج آزمون تحليل واريانس براى بررسى تفاوت كروهها در سه متغيرهاى يزوهش

\begin{tabular}{|c|c|c|c|c|c|c|c|c|}
\hline توان & اندازه اثر & معنادارى سطح & $\mathbf{F}$ & ميانكين مجموع & درجه & مجذوروات & منابع تغييرات & متغير \\
\hline.$/ 91$ & $\cdot / Y F$ & $\% \cdot r$ & $\Delta / 9 \mathrm{~V}$ & $\wedge 9 / 4$. & 1 & $\wedge 9 / 4$. & كرog & \\
\hline.$/ 99$ & $\cdot|4|$ &.$/ .1$ & $1 \% /$. & $\Delta F / V q$ & $I / Y V$ & $G T / Y \Delta$ & مراحل & \\
\hline$\cdot / 9 V$ & $\cdot / F F$ & $\% \cdot \cdot 1$ & $|f /| f$ & $\Delta r / \cdot \wedge$ & $I / Y V$ & GV/VY & تعامل مراحل با گروه & حرمت خود \\
\hline$\cdot / 91$ &.$/ 81$ & $\cdot / \cdots$ & $19 / \Gamma 1$ & $\Lambda \varepsilon / 4$. & 1 & $\Lambda q / 4$. & كروهـا & \\
\hline $1 / \cdot \cdot$ & $\cdot / \Delta r$ & $\cdot \cdots$ & $19 / \Delta r$ & rI/qr & $1 / 94$ & $r \Delta / r r$ & مراحل & خردهمقياس عمومى \\
\hline.$/ 99$ &.$/ 01$ & $\cdot / \cdots$ & $19 / \cdot 1$ & $r \mid / \cdot 9$ & $1 / 94$ & $\mu F / \mu$. & تعامل مر احل با گروه & \\
\hline$\cdot / \mathrm{V} 9$ & r & $\% / \% q$ & N/99 & $r F / .9$ & 1 & $r F / .9$ & كرو & \\
\hline $1 / \cdot$ & .191 & $\% \cdots$ & YN/GY & $1 \% / 9$. & $1 / 19$ & $19 / \pi r$ & مراحل & خردهمقياس تحصيلى \\
\hline.$/ 91$ &.$/ 09$ & $\cdot / \cdots$ & rQ/aY & $|Y / A|$ & $1 / 19$ & IF/AG & تعامل مراحل با گروه & \\
\hline . /9r & $\cdot / 41$ & $\cdot / \cdot r$ & IY/AS & $\mathrm{MT/VD}$ & 1 & MT/vo & كرو & \\
\hline $1 / \cdot \cdot$ & $\cdot 109$ & $\% \cdots$ & $r \mu / \Psi \Lambda$ & $1 . /$. & $1 / \& V$ & $\mid F / v$. & مراحل & خردهمقياس بدنى \\
\hline $1 / \cdot \cdot$ & .191 & $\cdot / \cdots$ & $r q / 4 q$ & $19 / 1$ & $1 / \& V$ & YF/V. & تعامل مر احل با گروه & \\
\hline$\cdot / \Delta \Lambda$ & $\cdot / r r$ & $\cdot / \cdot r$ & $\Delta / r r$ & $1 / \cdot 9$ & 1 & $1 / \cdot 9$ & كرومها & \\
\hline$\cdot / 9 V$ & $\cdot / 4$ & $\cdot \ldots$ & $\mid r / Y A$ & $9 / \cdot 1$ & $1 / \Delta r$ & Q/r & مراحل & خردهمقياس خانوادگى \\
\hline .194 &.$/ 19$ & $\cdot / \cdot r$ & $\mu / \mu$. & $r / l$. & $1 / \Delta r$ & r/r & تعامل مر احل با خروه & \\
\hline
\end{tabular}

1. Partial eta squared
1. Greenhouse-Geisser

2. Huynh-Feldt 


\begin{tabular}{|c|c|c|c|c|c|c|c|c|}
\hline$\cdot / \Delta r$ & $\cdot / r$ & $\cdot / \cdot \varphi$ & $F / \Delta 9$ & $9 / 99$ & 1 & 9199 & كروها كا & \\
\hline$\cdot / 19$ & .1 .9 & $\cdot / \mu$ & $1 / 19$ & $1 / 49$ & $1 / \pi$. & $1 / 9$. & مراحل & خردهمقياس اجتماعى \\
\hline$\cdot / r 1$ & .1 .4 & $\cdot / r F$ & $1 / Y V$ & $1 / \Delta 9$ & $1 / r$. & $r / \cdot r$ & تعامل مر احل با گروه & \\
\hline$\cdot / 99$ & $\cdot / \Delta F$ &.$/ .1$ & $1 Y / 9 \Lambda$ & $19 \Delta / \& \Lambda$ & 1 & $19 \Delta / F \wedge$ & كرومها & \\
\hline $1 / \cdot \cdot$ & $\cdot / 9$ & $\cdot \cdots$ & IW/r. & ITV/M & $1 / 14$ & $1 \Delta \Delta / 9$. & مراحل & تاب آورى \\
\hline $1 / \cdot \cdot$ & $\cdot / 9$ & $\cdot / \cdots$ & $\mid V / \Delta F$ & $\mid H F / Q \Delta$ & l/1r & $1 \Delta r=\Delta Q$ & تعامل مر احل با گُروه & \\
\hline
\end{tabular}

بيخيرى بـا يكـديخر تفـاوت معنادارى دارند. همجنين مجذور اتاى براى حرمت خود كلى و تاب آورى بيشــتر از • / • اســت كه نشــان مىدهد تفاوت بين گروهها در جامع بزرگك و قابل توجه است. همجينين جهت بررسى تفاوت گروه مداخله درمان متمركز بر شفقت بـا گروه گواه در متغيرهـاى يثزوهش در جدول ه نتايج مقايســه ميانگين

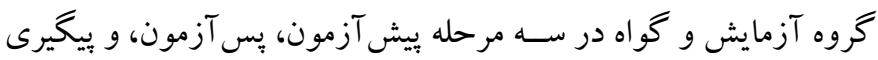
كزارش شده است.
بر اســاس نتـايج جـدول F، ميزان F اثر تعـامل مراحل و گرووه براى

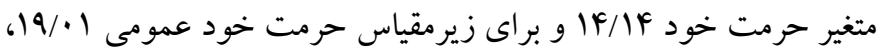

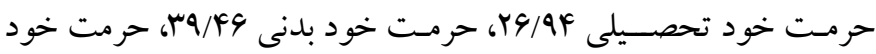

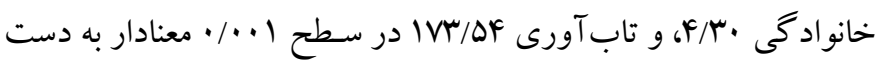
آمد و تنها در زير مقياس حرمت خود اجتماعى، اثر تعامل مراحل و گروه I/TV

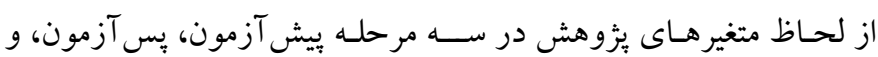

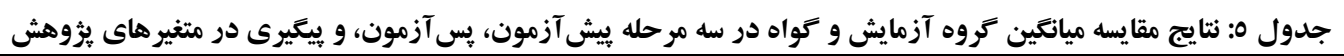

\begin{tabular}{|c|c|c|c|c|}
\hline سطح معنادارى & خطاى استاندارد بر آورد & تفاوت ميانكين كروه آزمايش با كواه & مرحله & متغير \\
\hline.$/ .9$ & $\cdot / \cdot V$ &.$/ 14$ & ي ييش آزمون & \\
\hline$\% \cdots$ & $\cdot / \pi \Delta$ & 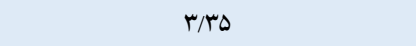 & يس آزمون & حرمت خود \\
\hline$\cdot / \cdots$ & $\cdot / F^{\prime}$ & r/4A & ييخيرى & \\
\hline$\cdot / 19$ & $\cdot / r r$ & $\cdot / \cdot \Delta$ & بيش آزمون & \\
\hline 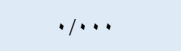 & $\cdot / \mu$ & 1/90 & يس آزمون & خردهمقياس عمومى \\
\hline$\cdot \cdots$ & . & $1 / 9$. & ييخيرى & \\
\hline$\cdot / \& \Delta$ & .1 .4 & $\cdot /$. & يِش آزمون & \\
\hline$\%$ & $\cdot / 19$ & $1 / 10$ & 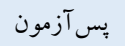 & خردهمقياس تحصيلى \\
\hline 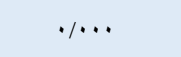 & $\cdot / r$ & $1 / \cdot 0$ & بيخيرى & \\
\hline.$/ 94$ & $\cdot / / r$ & $\%$ & ي بيش آزمون & \\
\hline 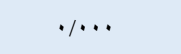 & $\cdot / \Lambda$ & $1 / \cdot \Delta$ & 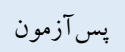 & خردهمقياس بدنى \\
\hline$\bullet \cdots$ & $\cdot / Y 1$ & $1 / \cdot 0$ & يِگيرى & \\
\hline$\cdot /$ & r/l & .110 & بيش آزمون & \\
\hline.$/ 4$ & $\cdot / 4 r$ & .19 & يس آزمون & خردهمقياس خانوادكى \\
\hline.$/ \cdot 1$ & $\cdot / r 1$ &.$/ 90$ & بيخيرى & \\
\hline.$/ 99$ & $\cdot / T V$ &.$/ . \Delta$ & ييش آزمون & \\
\hline$\%$ & . & . & يֶ آزمون & خردممقياس اجتماعى \\
\hline . & $\cdot / r \mid$ & $\cdot / 4$ & بيخيرى & \\
\hline$\cdot / \mu$ & $\cdot / F_{F}$ & $\cdot / r \Delta$ & يِيش آزمون & \\
\hline.$/ .1$ & .109 & $r / r V$ & يس آزمون & تاب آورى \\
\hline . & $\cdot / \Delta V$ & $r / \cdot \Delta$ & بيڤيرى & \\
\hline
\end{tabular}


كه واكنشيذيرى، ترس و قضساوتهاى بيجا كاهش يابد. زيرا اين

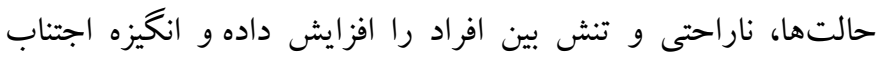

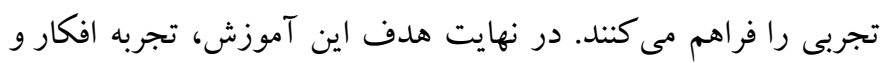

احساسات به همان گونه است كه به طور طبيعى اتفاق مى افتد (Y) (I ). با توجه به يافتهاى يُزوهش حاضـر، به نظر مىرسد كه حرمت خود در اين كود كان و نوجوانان بخش اصلى تمامى ارزش هاست؛ به اين معنا

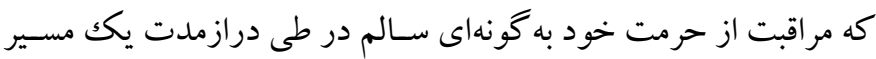

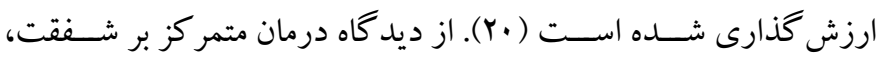

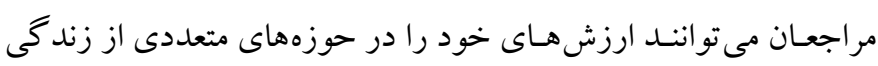
كشـف و بررسى كنند. از اين رو، درمانكر متمر كز بر شفقت بر اين باور

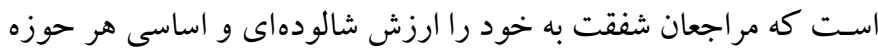

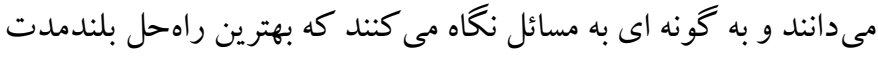

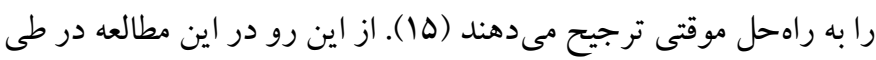
جلسات از مراجعان خواسته شد كه بر روى ارزشهاى مهاد مادام العمر تمركز

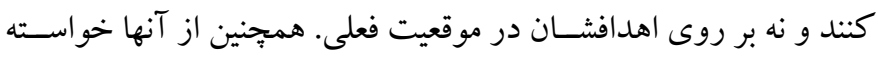

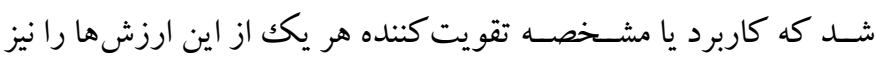
شناسايى و تعيين كنند (19).

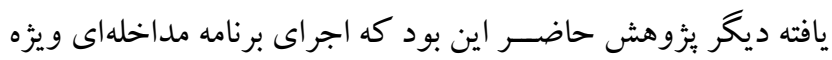

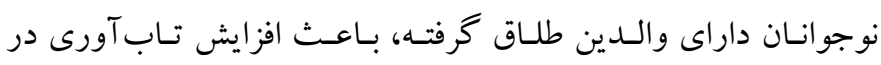

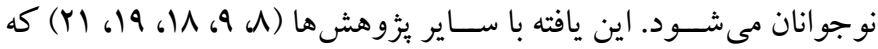

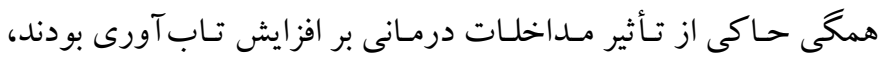

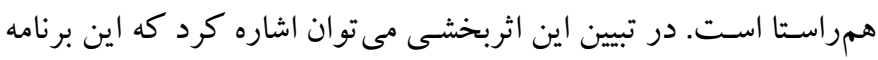

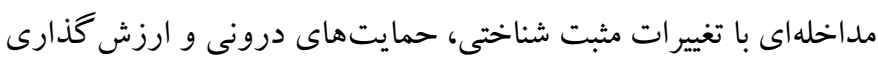

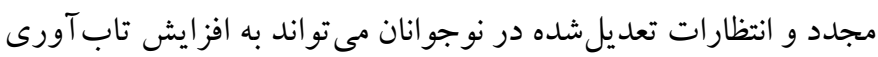

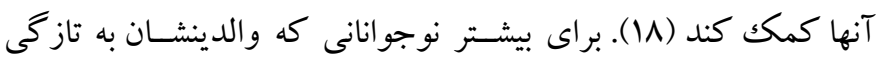

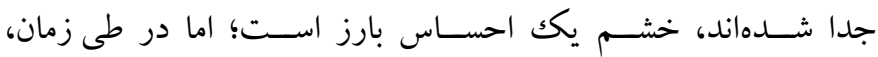
ماندكارى خشــم مى تواند در كاهش حرمت خودو و تابآورى مؤثر

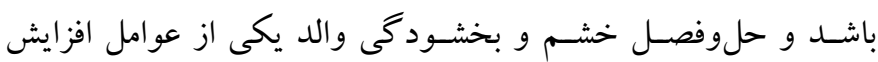

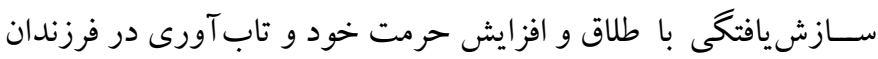
خانو اده طلاق اسـت. افزون بر آن يذيرش، ذهن بـ آكاهى، و و آكاهى فرد از

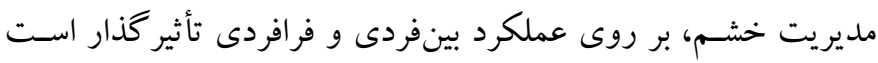
(Y). در اين بين درمانكر افراد را تشـويق مى كند تا افكار و هيجانات
با توجه به جدول ه در متغير حرمت خود كلى تفاوت ميانگين گروه

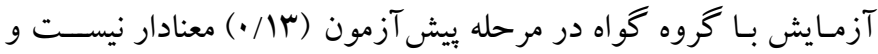

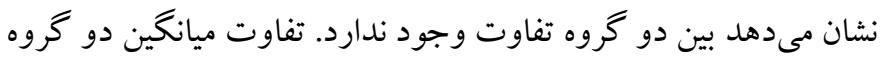

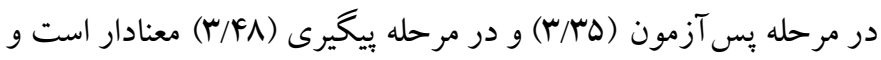

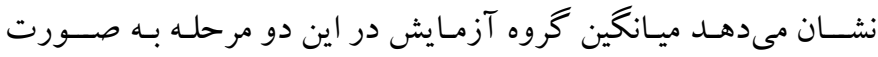

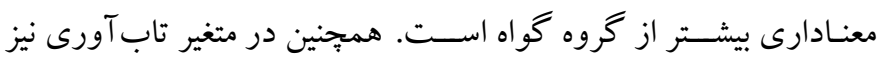

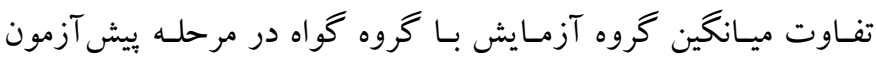

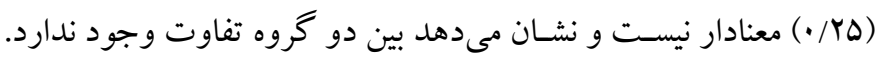

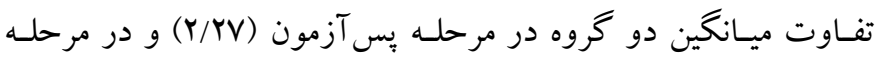

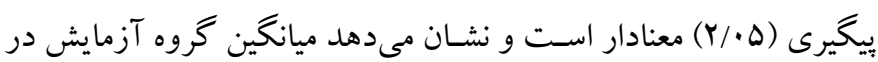
اين دو مرحله به صورت معنادارى بيشتر از گروه گُواه است.

\section{بحث و نتيجه كيرى}

يُزوهش حاضـر با هدف بررسى تأثير درمان متمر كز بر شـفقت بر بهبود

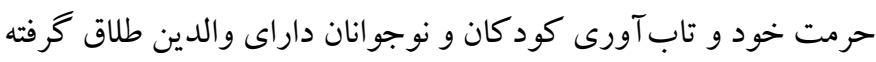

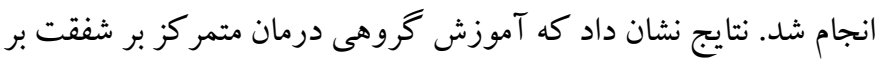
حرمت خود و تاب آورى گروه آزمايش در مرحله بس آزمون و بيخيرى

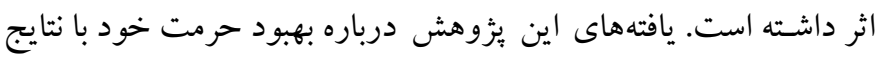

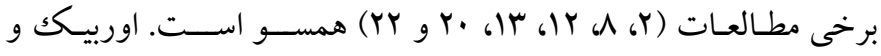
همكاران (Y) در مطالعه خود روى فرزندان بدســريرسـت داراى والدين طلاق نشـان دادند كه مشكلات خود نارزندهسازى، اعتماد به خود پيايين، و خودينداشت منفى، همكى ريشه در كود كى فرد و تأمين نيافتكى روانى او و حكايت از ضعف در توانايىهاى شناختى كود كان و نوجوانان دارد.

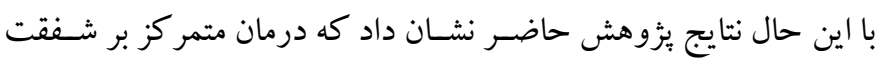

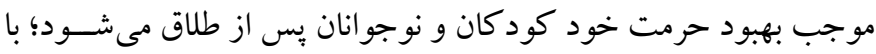
اين وجود به نظر مىرسـد كه اين درمان به مراجع اين امكان را مىدهد كه در وهله اول به تغيير روابط با تجارب درونىشـان، كاهش اجتناب

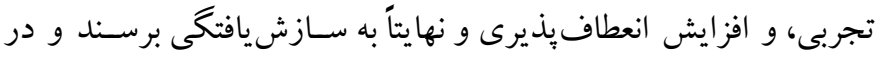

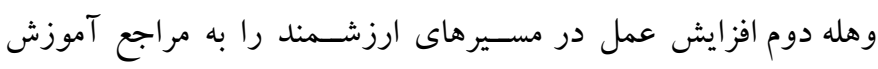

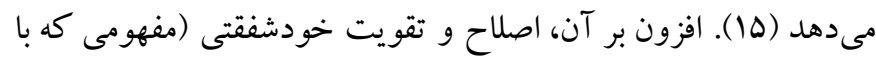
قضـاوت و انتقاد كه اغلب مراجع نسبت به افكار و احسـاسـاتش دارد،

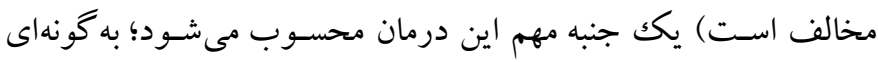


تمايل بيشـترى براى بذيرش نقش و مسـئوليت خود در حوادث منفى يس از طلاق دارند و مى توانند اتفاقات منفى طلاق را با آنجه هستند در

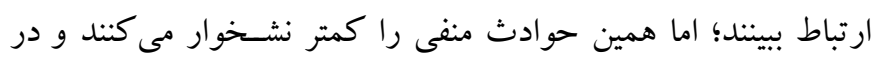
نتيجه در مواجهه با اشـتباهاتشـان، كمتر هيجانهاى منفى را تجربه رديه

مى كنند (Yq).

لازم به ذكر است كه با توجه به محدوديتهايى همجون پِّر بودن

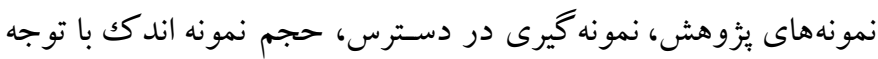

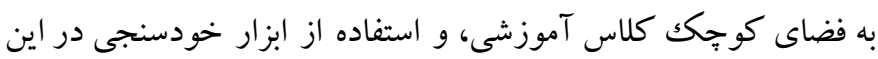
يزوهش، تعميميذيرى و اسـتنباط از نتايج اين مطالعه نيز بايد با احتياط

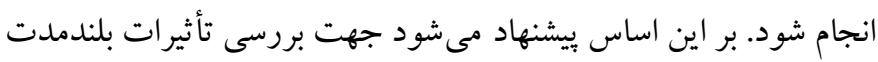

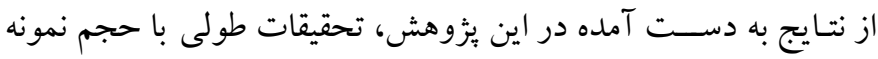

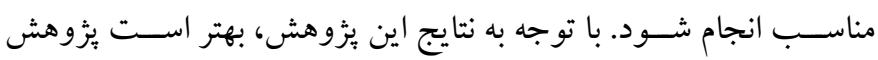

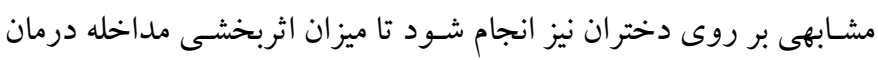

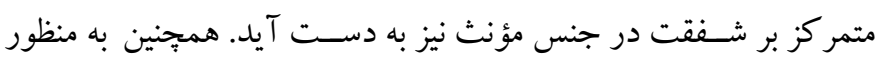

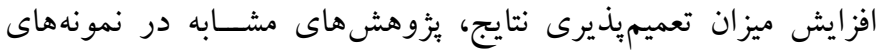

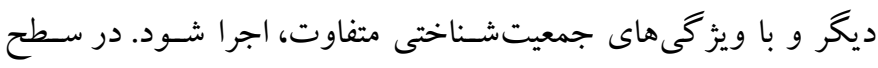

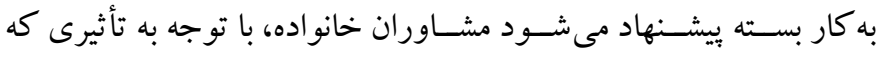

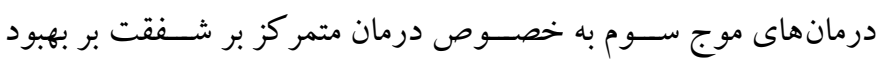
حرمـت خود و تـاب آورى فرزنـدان خـانو ادههـاى طلـاق دارنسلد، از اين

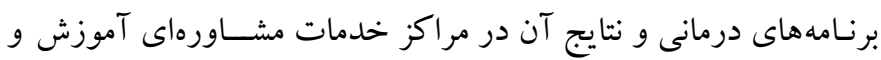
برورش، استفاده كنتد.

تشــكر و قــدردانىى: اين بثزوهش بـ از تأييد در كميسيون يزوهش مركز

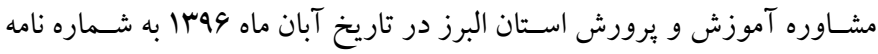

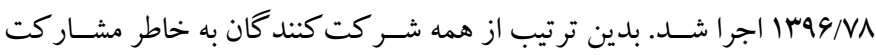

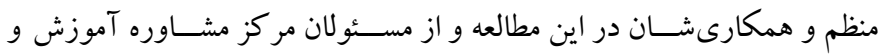

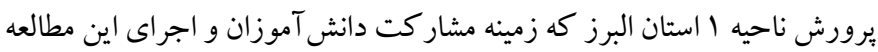

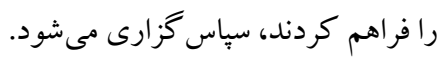
تضاد منافع: اين يُزوهش بر ایى نويسند كان هيج گَونه تضاد منافعى نداشته است.
مربوط به يكك فكر، احسـاس، رابطه، و رفتار را به صورت كامل تجربه

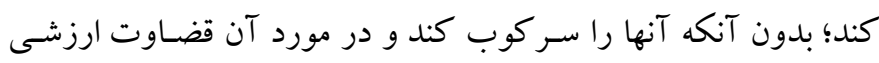
كند و هيجانات ثانويه مانند شـرم، گناه، بى اعتمادى، سـرزنش، و و و تحقير

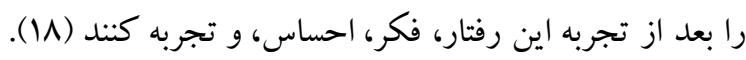

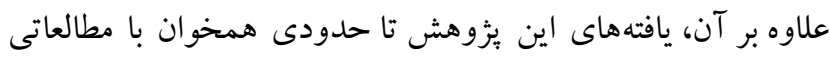

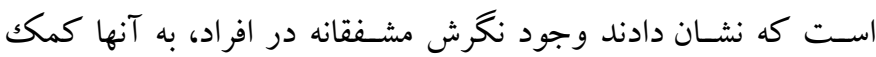
مى كند ميان خود و ديخران، ييوند احسـاس كنند و به واسـطه اين

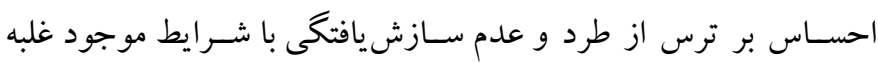

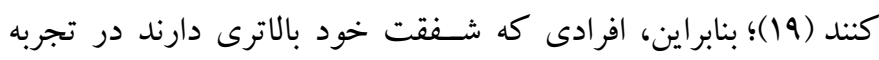

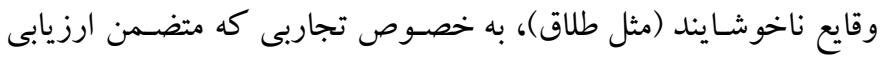

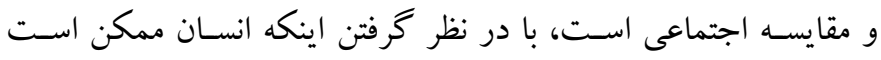

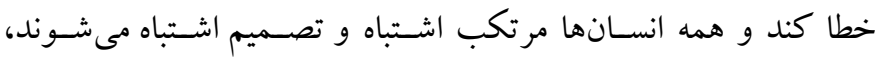
احسـاسـات منفى كمترى را تجربه مى كنند (مؤلفه اشستراكات انسـانى).

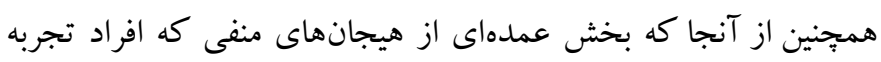

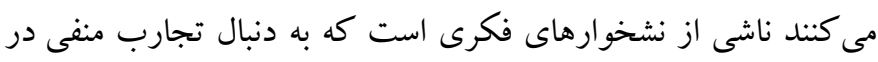

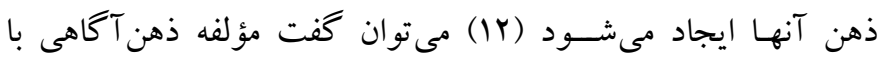
كاهش نشــخوارگرى افراد، منجر به كاهش هيجانهاى منفى (عدم

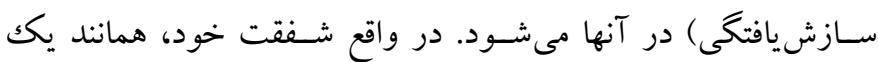

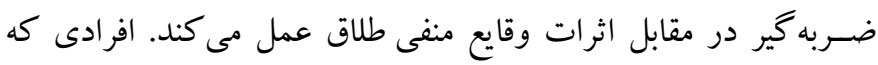

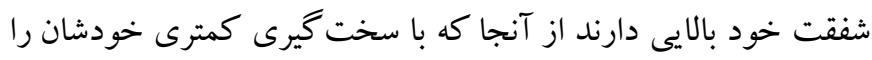

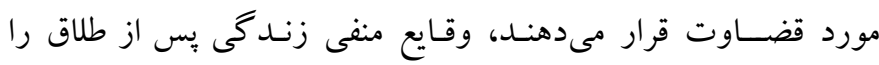

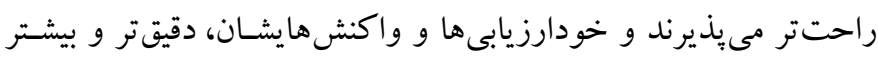

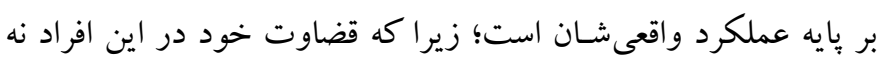

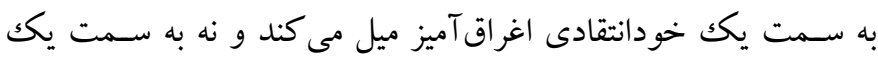
تورم خود دفاعى. بر اسـاس يافتههاى ليرى و همكاران (به نقل از ها ) شفقت خود در

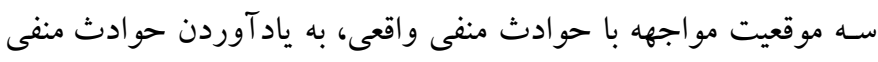

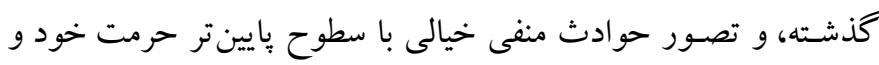

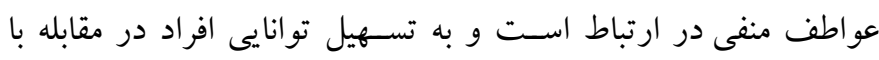
عواطف منفى منجر مىشـود. افرادى كه شـفقت خود باليى دارند، 


\section{References}

1. Mashhadi Ali, Hosieni Yazdi S.A, Asemi Z, \& Kimyaie S.A. The Effectiveness of CODIP on Improvement of Self-concept and Enhancement of Resilience in Children of Divorce.Quarterly Journal of Educational Psychology, 2015; 6(2): 48-58. [Persian]. [Link]

2. Overbeek M.M, De Schipper J.C, Willemen A.M, Lamers-Winkelman F, \& Schuengel C. Mediators and treatment factors in intervention for children exposed to interparental violence. Journal of Clinical Child \& Adolescent Psychology, 2017; 46(3); 411-427. [Link]

3. Kiviruusu O, Berg N, Huurre T, Aro H, Marttunen M, Haukkala A. Interpersonal Conflicts and Development of Self-Esteem from Adolescence to Mid-Adulthood. A 26-Year Follow-Up. PLoS One. 2016, 11(10); 1-29. [Link]

4. Weaver J.M, Schofield T.J. Mediation and moderation of divorce effects on children's behavior Problems. Journal of Family Psychology, 2015, 29 (1): 39-48. [Link]

5. Kazemi Aliabad Z, Khosrojavid M. Effect of Role Play Training on Self-esteem and Adjustment of Students. JCMH. 2018; 5 (1):105-116. [Persian]. [Link]

6. Halligan C, Chang I.J, Knox D. Positive effects of parental divorce on undergraduates. Journal of Divorce \& Remarriage, 2014; 55 (7): 557-567. [Link]

7. Moshkani M, Nuori E, Lotfi M, Ebadinya G. Effect of Phonological Awareness on Improving Reading and Self-esteem of Students with Dyslexia. JCMH. 2017; 4 (3):107-118. [Persian]. [Link]

8. Pedro-Carroll J.L. How parents can help children cope with separation/divorce. Encyclopedia on early childhood development.2011; Pp: 17-23.

9. Abel E.M, Chang-Canine U, Broussard K. A quasiexperimental evaluation of a school-based intervention for children experiencing family disruption. Journal of evidence-based social work, 2013; 10(2): 136-144. [Link]

10.Khabaz M, Bahjati Z, Naseri M. The relationship between social support and resiliency coping styles in adolescent boys. Journal of Applied Psychology, 2012; 5(4); 108-123. [Persian]. [Link]

11.Hass M, Graydon K. Source of resiliency a mong successful foster youth. Children and youth services review, 2009; 31: 457-463. [Link]

12. Saadati N, Rostami M, Darbani S A. Comparing the effectiveness of Acceptance and Commitment Therapy (ACT) and Compassion Focused Therapy
(CFT) on improving self-esteem and post-divorce adaptation in women. ijfp. 2017; 3 (2):45-58. [Persian]. [Link]

13.Connolly M. E, Green E. J. Evidence-based counseling intervention with children of divorce: Implications for elementary school counselor. Journal of School Counseling, 2008; 7(26); 1-37. [Link]

14.Navab M, Dehghani A, Salehi M. The Effectiveness of Compassion- Focused Group Therapy on Quality of Life and Change in the Goals and Priorities of Mothers of Children with Attention Deficit / Hyperactivity Disorder. JCMH. 2018; 5 (1):127-137. [Persian]. [Link]

15.Gilbert P. The origins and nature of compassion focused therapy. British Journal of Clinical Psychology, 2014; 53(1), 6-41. [Link]

16.Neff K.D, Germer C. K. A pilot study and randomized controlled trial of the mindful selfcompassion program. Journal of Clinical Psychology, 2013; 69(1), 28-44. [Link]

17.Tesh M, Learman J. Pulliam R.M. Mindful SelfCompassion Strategies for Survivors of Intimate Partner Abuse. Mindfulness, 2015; 6(2); 192-201. [Link]

18.Taher-Karami Z, Hossieni O, Dasht-Bozorgi Z. The Effectiveness of Compassion-Focused Therapy on Resiliency, Self-discrepancy, Hope and Psychological Well-being of Menopausal Women in Ahvaz. Community Health. 2018; 5(3):189-97. [Link]

19. Ghator Z, Pouryahya S M, Davarniya R, Salimi A, Shakarami M. The Effect of Compassion-Focused Therapy (CFT) on Resiliency of Women with Multiple Sclerosis (MS). Armaghane danesh. 2018; 23 (3). [Link].

20. Saeedi Z, Ghorbani N, Sarafraz M.R, Sharifian M.H. The effect of inducing self-compassion and selfesteem on the level of the experience of shame and guilt. Contemporary Psychology, 2013; 8(1): 91-102. [Link].

21.Trompetter H.R, Kleine E, Bohlmeijer E.T. Why Does Positive Mental Health Buffer Against Psychopathology? An Exploratory Study on SelfCompassion as a Resilience Mechanism and Adaptive Emotion Regulation Strategy. Cognitive Therapy and Research, 2017; 41(3); 459-468. [Link]

22.Andersen B, Rasmussen P.H. Transdiagnostic group therapy for people with self- critic and low self esteem, based on compassion focused therapy principles. Journal of Compassionate Health Care, 2017: 4(14); 1-11. [Link] 
تأثير درمان متمر كز بر شفقت بر تاب آورى كود كان داراى والدين طلاق گرفته

23.Hosogi M, Okada A, Fujii C, Noguchi K, Watanabe $\mathrm{K}$. Importance and usefulness of evaluating selfesteem in children. BioPsychoSocial Medicine, 2012; 6(9); 1-6. [Link].

24.Baezzat F, Saleh Sedghpour B. The comparison of self-esteem factors among students with dyslexia and normal students in third to fifth grades of primary schools of Tehran. Psychological Studies Faculty of Education and Psychology, 2009; 4(4); 65-80. [Link]

25.Conner KM, Davidson JR. Development of a new resilience scale: The Conner-Davidson Resilience scale (CD-RISC). Depress Anxiety. 2003; 18(2):7682. [Link]

26.Bigdeli I, Najafy M, Rostami M. The Relation of Attachment Styles, Emotion Regulation, and Resilience to Well-being among Students of Medical
Sciences. Iranian Journal of Medical Education. 2013; 13 (9):721-729. [Link]

27.Compell-Sills L, Stein MB. Psychometric analysis and refinement of the Conner-Davidson Resilience scale (CD-RISC): Validation of a 10 item measure of resilience. J Trauma Stress. 2007; 20(6): 10191028.[Link]

28.Keyhani M, Taghvaei D, Rajabi A, Amirpour B. Internal Consistency and Confirmatory Factor Analysis of the Connor-Davidson Resilience Scale (CD-RISC) among Nursing Female. Iranian Journal of Medical Education. 2015; 14 (10):857-865. [Persian]. [Link]

29.Gilbert P. An introduction to compassion focused therapy. Advances in Psychiatric Treatment, 2009; 15,199-208. [Link] 